\title{
Maize yield and nutrition during 4 years after biochar application to a Colombian savanna oxisol
}

\author{
Julie Major • Marco Rondon • Diego Molina • \\ Susan J. Riha $\cdot$ Johannes Lehmann
}

Received: 20 July 2009 /Accepted: 14 February 2010/Published online: 10 March 2010

(C) Springer Science+Business Media B.V. 2010

\begin{abstract}
The application of biochar (biomass-derived black carbon) to soil has been shown to improve crop yields, but the reasons for this are often not clearly demonstrated. Here, we studied the effect of a single application of 0,8 and $20 \mathrm{t} \mathrm{ha}^{-1}$ of biochar to a Colombian savanna Oxisol for 4 years (2003-2006),
\end{abstract}

Responsible Editor: Elizabeth (Liz) A. Stockdale.

Electronic supplementary material The online version of this article (doi:10.1007/s11104-010-0327-0) contains

supplementary material, which is available to authorized users.

J. Major · J. Lehmann $(\bowtie)$

Department of Crop and Soil Sciences, Cornell University,

Ithaca, NY 14853, USA

e-mail: CL273@cornell.edu

M. Rondon · D. Molina

Centro Internacional de Agricultura Tropical (CIAT),

A.A. 6713 Cali, Colombia

S. J. Riha

Department of Earth and Atmospheric Sciences,

Cornell University,

Ithaca, NY 14853, USA

Present Address:

M. Rondon

International Development Research Centre,

Ottawa, ON K1G 3H9, Canada

Present Address:

D. Molina

Centro de Investigaciones en Palma de Aceite,

cra 42 \# 33-07,

Villavicencio, Colombia under a maize-soybean rotation. Soil sampling to $30 \mathrm{~cm}$ was carried out after maize harvest in all years but 2005, maize tissue samples were collected and crop biomass was measured at harvest. Maize grain yield did not significantly increase in the first year, but increases in the $20 \mathrm{t} \mathrm{ha}^{-1}$ plots over the control were 28, 30 and $140 \%$ for 2004, 2005 and 2006, respectively. The availability of nutrients such as $\mathrm{Ca}$ and $\mathrm{Mg}$ was greater with biochar, and crop tissue analyses showed that $\mathrm{Ca}$ and $\mathrm{Mg}$ were limiting in this system. Soil $\mathrm{pH}$ increased, and exchangeable acidity showed a decreasing trend with biochar application. We attribute the greater crop yield and nutrient uptake primarily to the $77-320 \%$ greater available $\mathrm{Ca}$ and $\mathrm{Mg}$ in soil where biochar was applied.

Keywords Biochar C Colombia $\cdot$ Crop yield .

Exchangeable acidity $\cdot$ Maize $\cdot$ Oxisol .

Tropical savannas

\section{Introduction}

Soil fertility in high-rainfall, low-altitude regions of the tropics can be low due to rapid organic matter mineralization (Jenkinson and Ayanaba 1977), and the presence of highly weathered secondary minerals (van Wambeke 1992). However, fertility can be successfully improved using both inorganic and organic fertilizers. The major drawbacks of inorganic fertilizers are their low accessibility to resource-poor farmers (Garrity 2004) and their low efficiency in highly weathered soils (Baligar and 
Bennett 1986). While organic fertilizers are able to improve nutrient use efficiency, under tropical conditions they mineralize rapidly in soil and benefits through increases in organic matter last only for a few growing seasons (Bol et al. 2000; Diels et al. 2004; Tiessen et al. 1994). In contrast, biomass-derived black carbon (C), or biochar, is much more stable. While biochar must eventually mineralize in soil (Goldberg 1985; Schmidt and Noack 2000), a fraction remains in a very stable form with a ${ }^{14} \mathrm{C}$ age greater than that of the oldest soil organic matter (SOM) fractions (Krull et al. 2006; Pessenda et al. 2001; Skjemstad et al. 1996).

Soil nutrient availability in highly weathered tropical soils has repeatedly been increased by those biochar materials studied in prior experiments (Glaser et al. 2002; Lehmann et al. 2002, 2003; Rondon et al. 2007; Steiner et al. 2008). Nutrients applied with certain biochar materials can be responsible for short-term increases in crop growth (Lehmann et al. 2003). However, it has been hypothesized that the long-term effect of biochar on nutrient availability is due to an increase in surface oxidation and cation exchange capacity (CEC) (Liang et al. 2006), which intensifies over time (Cheng et al. 2006,2008 ) and can lead to greater nutrient retention in "aged" as opposed to "fresh" biochar. This mechanism has not been demonstrated under field settings over multiple years. If biochar additions can be credibly linked to greater nutrient retention of highly weathered soil, biochar management may provide a significant opportunity for sustainable improvements of soil fertility due to its high stability.

Therefore, our objective for this study was to investigate the long-term effects of biochar on soil fertility and crop yield. Our hypothesis was that biochar-amended soil provides more sites for the retention of base cations in acid tropical soils, thus retaining more of these in available form and resulting in greater crop yields and nutrient uptake.

\section{Materials and methods}

Field trial

The field experiment was located at Matazul farm in the Llanos Orientales, non-flooded savannas of Colombia (N 04 $14^{\prime} 15.2^{\prime \prime}$, W $0722^{\circ} 36^{\prime} 12.9^{\prime \prime}$ ) (Fig. 1). The soil is an isohyperthermic kaolinitic
Fig. 1 Location of field experiment, approximately $40 \mathrm{~km}$ east of Puerto Lopez

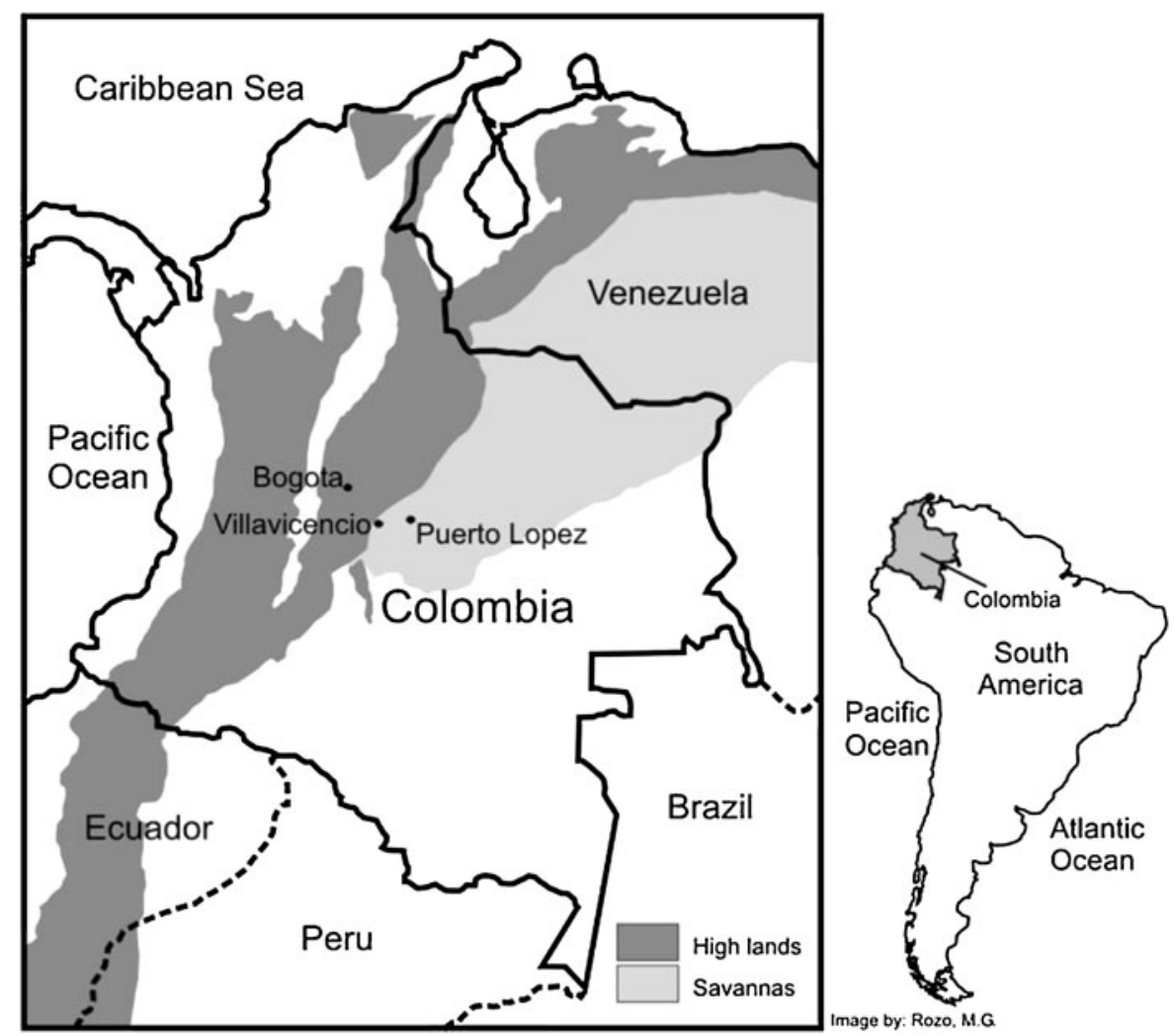


Typic Haplustox (Soil Survey Staff 1994), which developed from alluvial sediments originating in the Andes (Rippstein et al. 2001), containing $20 \mathrm{mg} \mathrm{g}^{-1}$ organic $\mathrm{C}, 1.3 \mathrm{mg} \mathrm{g}^{-1}$ total $\mathrm{N}, 6 \mathrm{mg} \mathrm{kg}^{-1}$ available $\mathrm{P}$, $40-44 \%$ clay, with a low $\mathrm{pH}$ (in $\mathrm{KCl}$ ) of 3.9 and a potential CEC of $110 \mathrm{mmol}_{\mathrm{c}} \mathrm{kg}^{-1}$ in the upper $10 \mathrm{~cm}$ (except for clay content which was measured in the upper $15 \mathrm{~cm}$ ). Long-term annual rainfall in the region is on average $2,200 \mathrm{~mm}$, as measured at a research station approximately $200 \mathrm{~km}$ northeast of the research plot. There is a marked dry season between January and March, and the average annual temperature is $26^{\circ} \mathrm{C}$ (Rippstein et al. 2001). Average annual rainfall during 2005 and 2006 at the study site was 2,354 and $2,226 \mathrm{~mm}$, respectively. It is possible to grow two cycles of annual crops during the rainy season. Initial vegetation consisted of native savanna grasses (mainly Trachypogon vestitus Andersson and T. plumosus Ness.) (Rippstein et al. 2001), and to our knowledge the experimental plot had never been tilled, cropped or amended prior to this study. This has to be recognized when comparing results to other studies on soils after long-term cultivation (Kimetu et al. 2008). However, fertility in native savanna soils at the experimental site is low with organic $\mathrm{C}$ contents of only about $20 \mathrm{mg} \mathrm{g}^{-1}$ despite the clayey soil texture, in contrast to often high fertility under other forest and savanna vegetation (Lobe et al. 2001; Zingore et al. 2005; Kimetu et al. 2008). In December 2002, the experimental area was chisel plowed and lime (dolomite) was applied at $2.2 \mathrm{t} \mathrm{ha}^{-1}$, and incorporated to $30 \mathrm{~cm}$ using two passes of a chisel plough. Nine days later, biochar (see Table 1) was applied in a randomized complete block design with three replicates. Biochar incorporation was accomplished with one pass of a disc harrow to a depth of $5 \mathrm{~cm}$. Application rates were 0,8 and $20 \mathrm{t} \mathrm{ha}^{-1}$, for a total of nine experimental plots, each measuring 4 by $5 \mathrm{~m}$. Plots were separated by a $1 \mathrm{~m}$ buffer within blocks and a $2 \mathrm{~m}$ buffer between blocks. Lime and biochar were applied on only one occasion in 2002. Wood biochar commercially made for cooking using the traditional mound kiln technique (Brown 2009) was ground using a tractor and a roller, to pass through a 5-mm mesh. Details on feedstocks used to make the biochar and production conditions are not available. Beginning in May 2003 and until December 2006, plots were cropped to a maize (Zea mays L.) - soybean (Glycine $\max (\mathrm{L}$.) Merr.) rotation. The
Table 1 Properties of wood biochar made commercially for cooking and applied to a Colombian savanna Oxisol in 2002. Values shown are averages of two analytical replicates

\begin{tabular}{llc}
\hline & & Biochar \\
\hline $\mathrm{pH}$ & $\left(\mathrm{H}_{2} \mathrm{O}\right)$ & 9.20 \\
$\mathrm{pH}$ & $(\mathrm{KCl})$ & 7.17 \\
Total C & $(\%)$ & 72.9 \\
Total N & $(\%)$ & 0.76 \\
$\mathrm{C} / \mathrm{N}$ & & 120 \\
$\mathrm{H} / \mathrm{C}$ & & 0.018 \\
$\mathrm{O} / \mathrm{C}$ & & 0.26 \\
$\mathrm{Ash}$ & $(\%)$ & 4.6 \\
$\mathrm{Ca}$ & $\left(\mu \mathrm{g} \mathrm{g}^{-1}\right)$ & 330.7 \\
$\mathrm{Mg}^{\mathrm{a}}$ & $\left(\mu \mathrm{g} \mathrm{g}^{-1}\right)$ & 48.9 \\
$\mathrm{P}^{\mathrm{a}}$ & $\left(\mu \mathrm{g} \mathrm{g}^{-1}\right)$ & 29.8 \\
$\mathrm{~K}^{\mathrm{a}}$ & $\left(\mu \mathrm{g} \mathrm{g}^{-1}\right)$ & 463.8 \\
$\mathrm{Sr}^{\mathrm{a}}$ & $\left(\mu \mathrm{g} \mathrm{g}^{-1}\right)$ & 2.6 \\
$\mathrm{Potential} \mathrm{CEC}^{\mathrm{a}}$ & $\left(\mathrm{mmol}_{\mathrm{c}} \mathrm{kg}^{-1}\right)$ & 111.9 \\
\hline
\end{tabular}

${ }^{\text {a }}$ Available nutrients extracted with Mehlich III (Mehlich 1984) and quantified by inductively coupled atomic emission spectroscopy (ICP-AES)

initial design also included plots seeded to pasture grasses and plots left to savanna vegetation, but only the crop rotation plots were used for the work reported here. No tillage was carried out after biochar incorporation, simulating no-till soil management.

Maize seeds were treated with fungicides (Carboxin and Thiram), and soybean seeds with both fungicides and Rhyzobium inoculum. Both maize and soybean were seeded using hand tools with fertilizer placed in a parallel furrow approximately $10 \mathrm{~cm}$ from the seed row. After seeding, side-dressed fertilizer was applied by hand to the soil surface, on crop rows, to all plots. Maize was seeded on 22 May 2003 and 30 April 2004 (variety information unavailable), and hybrid Pioneer ${ }^{\circledR} 3041$ was seeded on 17 May 2005 and 10 May 2006, all at 62,500 plants $\mathrm{ha}^{-1}(6.25$ plants $\mathrm{m}^{-2}$ ). Short cycle, indeterminate soybean was seeded on 22 September 2004 (variety information unavailable), and varieties Corpoica Libertad 4 and Corpoica Superior 6 were seeded on 11 October 2005 and 15 September 2006, respectively, all at 400,000 plants $\mathrm{ha}^{-1}$. Dates given are for the last, successful seeding. Re-seeding (up to twice) was necessary due to bird, insect and reptile damage. Initial fertilization took place at first seeding and was not repeated when 
re-seeding was necessary (Table 2). Weeds, insects and fungal diseases were controlled as necessary using herbicides and pesticides according to local practices. At soybean seeding in 2006, a powdered insecticide was used at a locally recommended dose in seed furrows on some areas of plots.

Soil sampling and analysis

After harvesting maize in 2003, 2004 and 2006, soil was sampled in the control and $20 \mathrm{t} \mathrm{ha}^{-1}$ plots (and $8 \mathrm{tha}^{-1}$ in 2006 only) in depth increments of $0-0.05$, $0.05-0.1,0.1-0.2$ and $0.2-0.3 \mathrm{~m}$. A small pit was dug inside each plot and samples taken along one side of the pit. On 25-26 April 2006, additional samples were taken to $2.0 \mathrm{~m}$ using a hand-held core auger for quantification of extractable inorganic $\mathrm{N}$ only in treatments receiving 0 and $20 \mathrm{t} \mathrm{ha}^{-1}$ biochar additions. For depth increments $0-0.15$ and $0.15-0.3 \mathrm{~m}$, five profiles were sampled on old maize rows and five half-way between rows, in each plot. For increment 0.3-0.6 m, three profiles were sampled on old maize rows and two in between. For increments 0.6-1.2 and 1.2-2.0 $\mathrm{m}$, two profiles were sampled, one at each location. Samples below $0.3 \mathrm{~m}$ were also used for determining extractable cations, $\mathrm{P}, \mathrm{pH}$ and total $\mathrm{C}$ and
$\mathrm{N}$ contents. Soil from each depth increment and profile was collected in buckets and thoroughly mixed manually before a subsample was taken for analysis. During sampling soil subsamples were kept on ice in an insulated box.

Immediately after sampling to $2.0 \mathrm{~m}$, moist subsamples were weighed and set aside for moisture determination after drying at $105^{\circ} \mathrm{C}$ for $24 \mathrm{~h}$ and reweighed. Thirty grams of moist soil were weighed into plastic bottles, and $150 \mathrm{ml}$ of $1 \mathrm{~N} \mathrm{KCl}$ were added for extraction of inorganic N. Shakers were not available near the field location, and jars were shaken by hand for $5 \mathrm{~min}$ (Lehmann et al. 1999). Jars were then kept at $4{ }^{\circ} \mathrm{C}$ for several days until soil settled, and $20 \mathrm{ml}$ supernatant was transferred to small plastic vials using pipettes (Renck and Lehmann 2004) and kept frozen until analysis. Ammonium and nitrate concentrations of soil extracts were determined colorimetrically on a segmented flow analyzer (Autoanalyzer 3 by Bran+Luebbe, Rochester NY, USA). Data were corrected for $\mathrm{N}$ contributed by the extractant and transformed to represent concentrations on a dry soil basis. Leftover soil was air-dried, crushed and passed through an aluminum sieve with $2 \mathrm{~mm}$ circular openings. Available nutrients were extracted from $2.5 \mathrm{~g}$ of air-dried soil using $25 \mathrm{ml}$ of

Table 2 Fertilizer application rates $\left(\mathrm{kg} \mathrm{ha}^{-1}\right)$. Nitrogen was applied as urea unless otherwise indicated, $\mathrm{K}$ as $\mathrm{KCl}$ and $\mathrm{P}$ as acidified rock phosphate

\begin{tabular}{|c|c|c|c|c|c|c|c|c|c|c|c|}
\hline Year & Crop & Application date & $\mathrm{N}$ & $\mathrm{P}$ & $\mathrm{K}$ & $\mathrm{Ca}$ & $\mathrm{Mg}$ & $\mathrm{S}$ & $\mathrm{B}$ & $\mathrm{Cu}$ & $\mathrm{Zn}$ \\
\hline 2002 & & $10 \mathrm{Dec}$ & & & & 509 & 199 & & & & \\
\hline 2003 & Maize & Total & 165 & 43 & 86 & 2.9 & 16.2 & 10 & 0.4 & - & 4.5 \\
\hline \multirow[t]{2}{*}{2004} & Maize & Total & 170 & 33 & 84 & 2.1 & 15.6 & 10 & 0.3 & - & 4.0 \\
\hline & Soybean & Total & 87 & 39 & 63 & - & 19.2 & 13 & 0.9 & - & 4.7 \\
\hline \multirow[t]{5}{*}{2005} & Maize & 4 May & 30 & 30 & 25 & 1.8 & 3.0 & 1.6 & 0.3 & - & 1.6 \\
\hline & & 9 Jun & 46 & - & 62 & - & - & - & - & - & - \\
\hline & & 21 Jun & 80 & - & 25 & - & - & - & - & - & - \\
\hline & & Total & 156 & 30 & 112 & 1.8 & 3.0 & 1.6 & 0.3 & - & 1.6 \\
\hline & Soybean & $12 \mathrm{Sep}^{\mathrm{a}}$ & 16 & 10 & 110 & 17.0 & 4.0 & 5.0 & 0.3 & 0.3 & 1.7 \\
\hline \multirow[t]{5}{*}{2006} & Maize & $27 \mathrm{Apr}$ & 31 & 30 & 36 & - & 12.5 & 15.6 & 0.3 & 0.3 & 1.6 \\
\hline & & 27 May & 58 & - & 62 & - & - & - & - & - & - \\
\hline & & 9 Jun & 70 & - & 38 & - & - & - & - & - & - \\
\hline & & Total & 159 & 30 & 138 & - & 12.5 & 15.6 & 0.3 & 0.3 & 1.6 \\
\hline & Soybean & $7 \mathrm{Sept}^{\mathrm{b}}$ & 16 & 10 & 104 & - & 7.2 & 12.0 & 0.2 & 0.3 & 1.7 \\
\hline
\end{tabular}

${ }^{\mathrm{a}}$ Less than $2 \mathrm{~kg} \mathrm{ha}^{-1} \mathrm{~N}\left(82 \%\right.$ as $\mathrm{KNO}_{3}$ and $2 \%$ as urea), $0.05 \mathrm{~kg} \mathrm{ha}^{-1} \mathrm{P}$ and $2 \mathrm{~kg} \mathrm{ha}^{-1} \mathrm{~K}$ total applied as foliar fertilizer on 24 and 28 Oct, and 8 Nov. On these dates trace amounts $\left(<3 \mathrm{~g} \mathrm{ha}^{-1}\right)$ of $\mathrm{Ca}, \mathrm{Mg}, \mathrm{S}, \mathrm{B}, \mathrm{Cu}$ and $\mathrm{Zn}$ were also applied

${ }^{\mathrm{b}}$ Less than $1 \mathrm{~kg} \mathrm{ha}^{-1} \mathrm{~N}\left(82 \%\right.$ as $\mathrm{KNO}_{3}$ and $2 \%$ as urea) as foliar fertilizer, plus foliar application of gibberellin on 14 Oct 
Mehlich III solution (Mehlich 1984) and horizontal shaking for $5 \mathrm{~min}$. Upon filtering, extracts were analyzed by atomic emission spectrometry (IRIS Intrepid by Thermo Elemental, Franklin MA, USA). Soil $\mathrm{pH}$ was determined in a 1:2.5 soil:water or $1 \mathrm{~N}$ $\mathrm{KCl}$ mixture, agitated three times over the course of $1 \mathrm{~h}$, and measured using a gel electrode (Symphony by VWR, West Chester PA, USA). Exchangeable acidity was determined by extracting $5 \mathrm{~g}$ of soil with $25 \mathrm{ml} 1 \mathrm{~N} \mathrm{KCl}$, shaking lightly, and allowing to rest for $30 \mathrm{~min}$. Samples were then filtered and extraction bottles washed three times with $25 \mathrm{ml}$ of $1 \mathrm{~N} \mathrm{KCl}$. Phenolphthalein was added to the extracts, and these were titrated using $0.01 \mathrm{~N} \mathrm{NaOH}$. Potential cation exchange capacity (CEC) was determined by extraction with $1 \mathrm{~N}$ ammonium acetate at $\mathrm{pH} 7$, flushing three times with isopropyl alcohol followed by extraction with $2 \mathrm{~N} \mathrm{KCl}$. The ammonium content of the $\mathrm{KCl}$ extract was determined colorimetrically using Nessler's reagent (Naude 1927) on a Technicon ${ }^{\circledR}$ flow analyzer. Effective CEC was calculated by summing the amount of charge per unit soil from all cations extracted by Mehlich III except Al, and exchangeable acidity. Wang et al. (2004) found a good correlation between cations extracted using the Mehlich III solution and ammonium acetate at $\mathrm{pH}$ 7. Base saturation (BS) was obtained by dividing the total amount of charge per unit soil from $\mathrm{Ca}, \mathrm{K}$ and $\mathrm{Mg}$ by effective CEC. Total $\mathrm{C}$ and $\mathrm{N}$ contents were determined by combustion on an isotope ratio mass spectrometer (Europa Hydra 20/20 by Europa Scientific, Crewe, UK).

The point of zero net charge (PZNC) of the soil in 2006 was determined on samples of the 0 and $20 \mathrm{tha}^{-1}$ biochar application rates, with all replicates combined. The method using $\mathrm{K}$ and $\mathrm{Cl}$ ions described by Cheng et al. (2008) was used, except quadratic curves were used only to describe the soils' positive charge. Linear and hyperbolic curves were used for negative charge in the control and biochar amended soils, respectively.

Biochar was analyzed similarly to soil, except double extractions were used for potential CEC determination (Cheng et al. 2006) and the ratio of biochar:water or $1 \mathrm{~N} \mathrm{KCl}$ for $\mathrm{pH}$ measurement was 1:10. The $\mathrm{H}$ content of biochar was measured after combustion on an automatic gas analyzer (PDZ Europa 20-20, Heckatech HT by Europa Scientific, Crewe, UK). Oxygen content was calculated by difference using the ash, $\mathrm{C}$ and $\mathrm{H}$ contents.
Crop samples and measurements

Maize leaf tissue samples were taken in 2006 from the flag leaf of ten marked plants per plot at tasseling. Squares of about 50 by $50 \mathrm{~mm}$ were cut from one edge towards the midrib, halfway down the leaf. These were kept on ice in the field and frozen until oven drying at $70^{\circ} \mathrm{C}$ for $72 \mathrm{~h}$. At harvest, maize ears were harvested from 2 linear meters on different rows, avoiding plot edges. Husks were left on the plants. Ears were shelled by hand, and grain and cobs were dried first in the sun and then in an oven at $60^{\circ} \mathrm{C}$ for $72 \mathrm{~h}$. Grain moisture after drying was determined using a hand-held moisture tester (John Deere, Moline IL, USA), and grain yield is reported on a $15 \%$ moisture content basis. In each plot, vegetative biomass with ears removed was harvested at ground level from 1 linear meter, wet weight recorded and subsamples consisting of 2 whole maize plants were weighed and taken to the lab. After oven drying at $70^{\circ} \mathrm{C}$ to constant weight (about $48 \mathrm{~h}$ ), dry weights were determined. Vegetative biomass from harvest, dried leaf material from tasseling and subsamples of grain were ground using a laboratory mill (Thomas Wiley, Philadelphia PA, USA) to pass a 1-mm sieve, packaged in sealed plastic bags and stored until analysis by acid block digestion with nitric acid and hydrogen peroxide, followed by determination of total nutrient content by atomic emission spectrometry (IRIS Intrepid by Thermo Elemental, Franklin MA, USA). Samples of vegetative maize tissue from 2006 were not available for analysis.

In 2006, soybean leaf samples were collected at full bloom from the newest mature, trifoliate leaf at the top of plants marked for measuring height. Due to problems with pest damage and insecticide toxicity, soybean growth was heterogeneous. At harvest, all biomass was harvested on 2-4 linear meters of unaffected areas. Biomass was manually separated into seeds and vegetative plant parts, dried, weighed, ground and analyzed as above. Soybean seed, due to its high oil content, was analyzed for total nutrients by dry ashing at $450^{\circ} \mathrm{C}$ for $7 \mathrm{~h}$, adding hydrogen peroxide and ashing again at $450^{\circ} \mathrm{C}$ for $2.5 \mathrm{~h}$. The ash was dissolved in a hydrochloric acid matrix and analyzed by atomic emission spectrometry (CIROS by SPECTRO Analytical Instruments, Kleve, Germany). 
Statistical analyses

All data was analyzed using PROC GLM of the SAS software package (SAS Institute Inc 2003). Treatment means were separated using the Student $\mathrm{T}$ test. Upon inspecting residual plots, it was deemed necessary to $\log$ transform data for soil available $\mathrm{Ca}, \mathrm{K}, \mathrm{Mg}, \mathrm{Mn}$, Mo, P, S, and Sr in order to comply with the model's assumption of equal variance.

\section{Results}

Crop yield and nutrient uptake

In the first year after biochar application, no significant effect on crop yield was observed $(p>0.05)$. In subsequent years, however, maize yield increased with increasing biochar application rate, and the positive effect of biochar was most prominent in 2006 when absolute yields were the lowest (Fig. 2). Grain yield from soybean was only available in 2006 due to deer grazing in the field in previous years, and no significant differences between treatments were observed ( $p>0.05$, data not shown).

The harvest index (HI) of maize (grain mass divided by total mass) was significantly lower ( $p>$ 0.05 ) in 2006 than in other years, in both the control and $20 \mathrm{t} \mathrm{ha}^{-1}$ biochar amended plots (the average $\mathrm{HI}$ for 2003 to 2005 was 0.47 for both treatments, and in

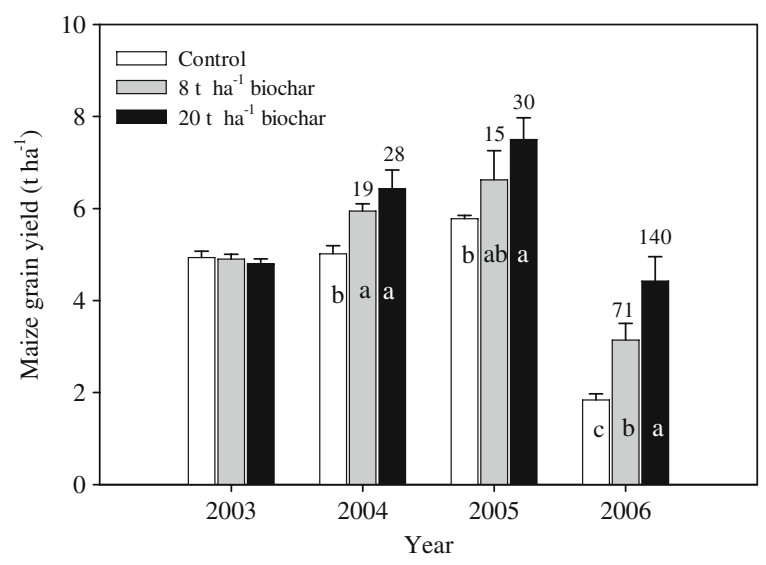

Fig. 2 Maize grain yield on a Colombian savanna Oxisol amended with biochar in late $2002( \pm$ SE, $n=3)$. Numbers above bars are percent yield increase compared to the optimally managed control, and different letters indicate significant differences between means $(p<0.05)$ within single years
2006 the HI was 0.37 and 0.42 for the control and $20 \mathrm{t}$ biochar $\mathrm{ha}^{-1}$ application rate, respectively). Interestingly, between 2003 and 2005, no differences in HI were observed in the control plots, while the high biochar application rate produced significantly $(p<0.05)$ increasing HI values in each of these years (0.44 in 2003, 0.47 in 2004 and 0.50 in 2005).

Total nutrient uptake by the maize crop also increased overall with biochar application (Fig. 3), or decreased in the case of Al. Strontium, which is a common contaminant in fertilizers (Senesi et al. 2005), has a similar behavior in soil and plants as Ca (Aberg 1995). In this study, total Sr uptake by plants increased with increasing biochar application. For maize leaf samples taken at tasseling in 2006, concentrations of $\mathrm{Ca}$ (1.08 and $1.36 \mathrm{~g} \mathrm{~kg}$ dry matter ${ }^{-1}$ for 0 and $20 \mathrm{t}$ biochar $\mathrm{ha}^{-1}$, respectively) and $\mathrm{Mg}$ (0.92 and $1.03 \mathrm{~g} \mathrm{~kg} \mathrm{dry}$ matter $^{-1}$ ) were also significantly higher with the high biochar application rate than the control $(p<0.05)$. For soybean samples, total uptake of $\mathrm{K}$ (45.5 and $50.7 \mathrm{~kg} \mathrm{ha}^{-1}$ respectively), $\mathrm{Cu}$ (25.7 and 28.3 $\mathrm{g} \mathrm{ha}^{-1}$ ) and $\mathrm{Mn} \mathrm{(89.8} \mathrm{and}$ $129.1 \mathrm{~g} \mathrm{ha}^{-1}$ ) in 2006 was significantly greater with biochar application $(p<0.05)$. Total uptake of $\mathrm{Sr}$ was not measured for soybean. Also, the Mn (64.2 and $97.5 \mathrm{mg} \mathrm{kg}$ dry matter ${ }^{-1}$, respectively) content of soybean leaf tissue at flowering was greater when biochar had been applied.

Calcium concentration in maize grain decreased significantly $(p<0.05)$ after 2004 in all treatments, and $\mathrm{Mg}$ concentrations decreased over the duration of the experiment, significantly so $(p<0.05)$ in the control and high biochar application plots (Fig. 4). With vegetative tissue these decreasing trends were less clear, especially in the case of $\mathrm{Mg}$.

\section{Soil properties}

While nitrate accumulation below $60 \mathrm{~cm}$ depth was observed (data not shown), no significant differences $(p>0.05)$ were found between biochar-amended and control plots for inorganic $\mathrm{N}$ content before seeding maize in 2006. Over most years and depth increments to $0.3 \mathrm{~m}$, biochar application resulted in significantly $(p<0.05)$ greater available $\mathrm{Ca}(101-320 \%$ for significant differences between the control and $20 \mathrm{t} \mathrm{ha}^{-1}$ application rate), Mg (64-217\%), Mn (136-342\%), Mo (573-860\%) and $\mathrm{Sr}$ (251-591\%), while the availability of $\mathrm{Al}$ and $\mathrm{Fe}$ showed a decreasing trend 

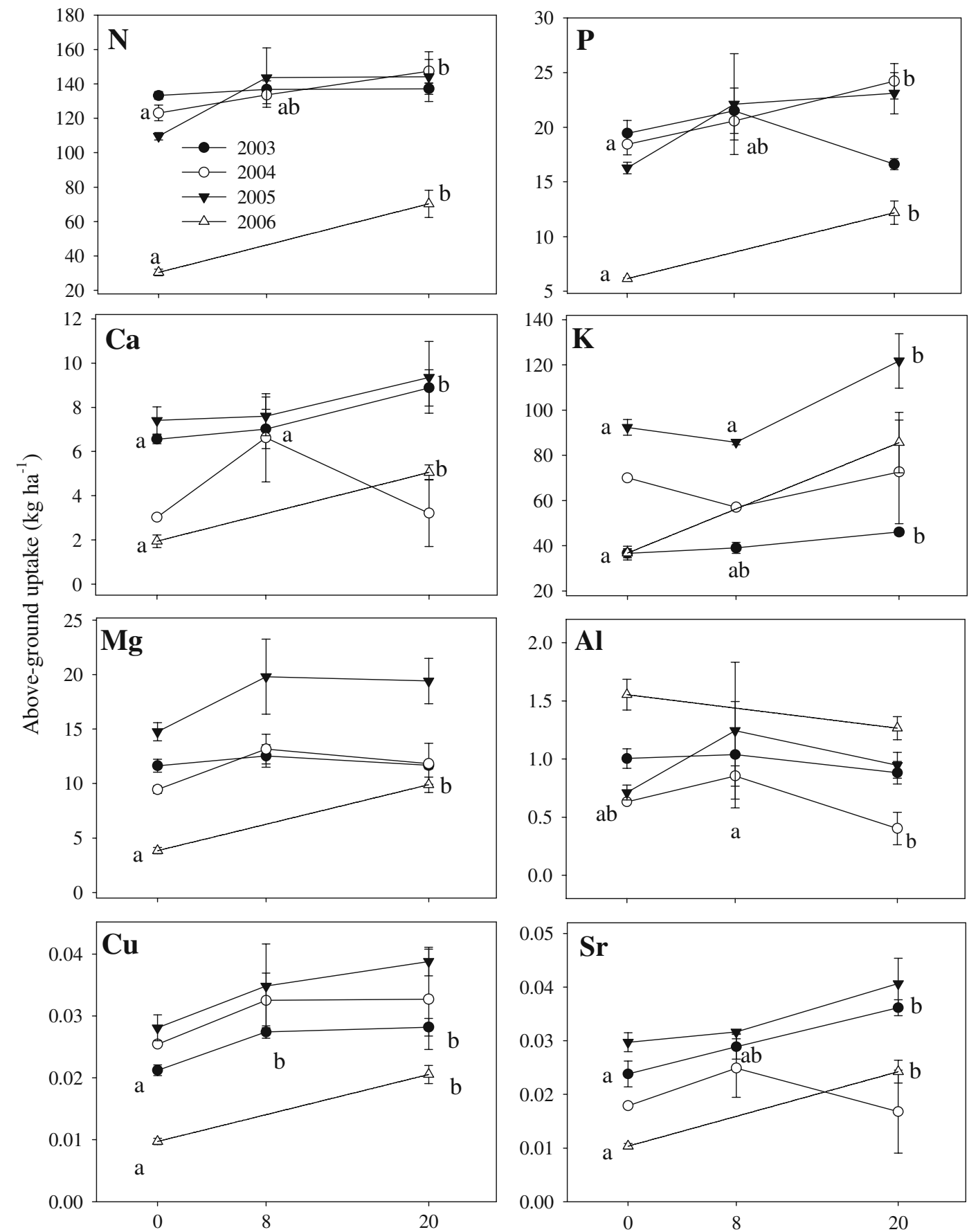

Biochar application rate $\left(\mathrm{t} \mathrm{ha}^{-1}\right)$
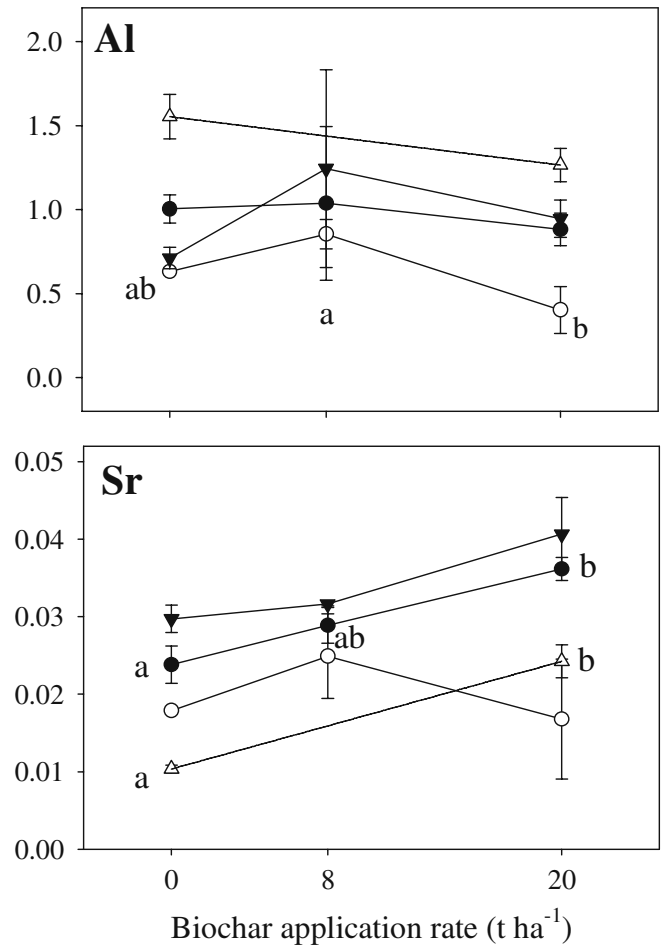

Fig. 3 Total nutrient uptake by maize crops grown during 4 years after biochar application to a Colombian savanna Oxisol ( \pm standard error, $n=3$ ). Different letters indicate

significant differences between treatment means $(p<0.05)$ within single years, letters not shown when differences not significant. Note different scales for $\mathrm{y}$-axes 

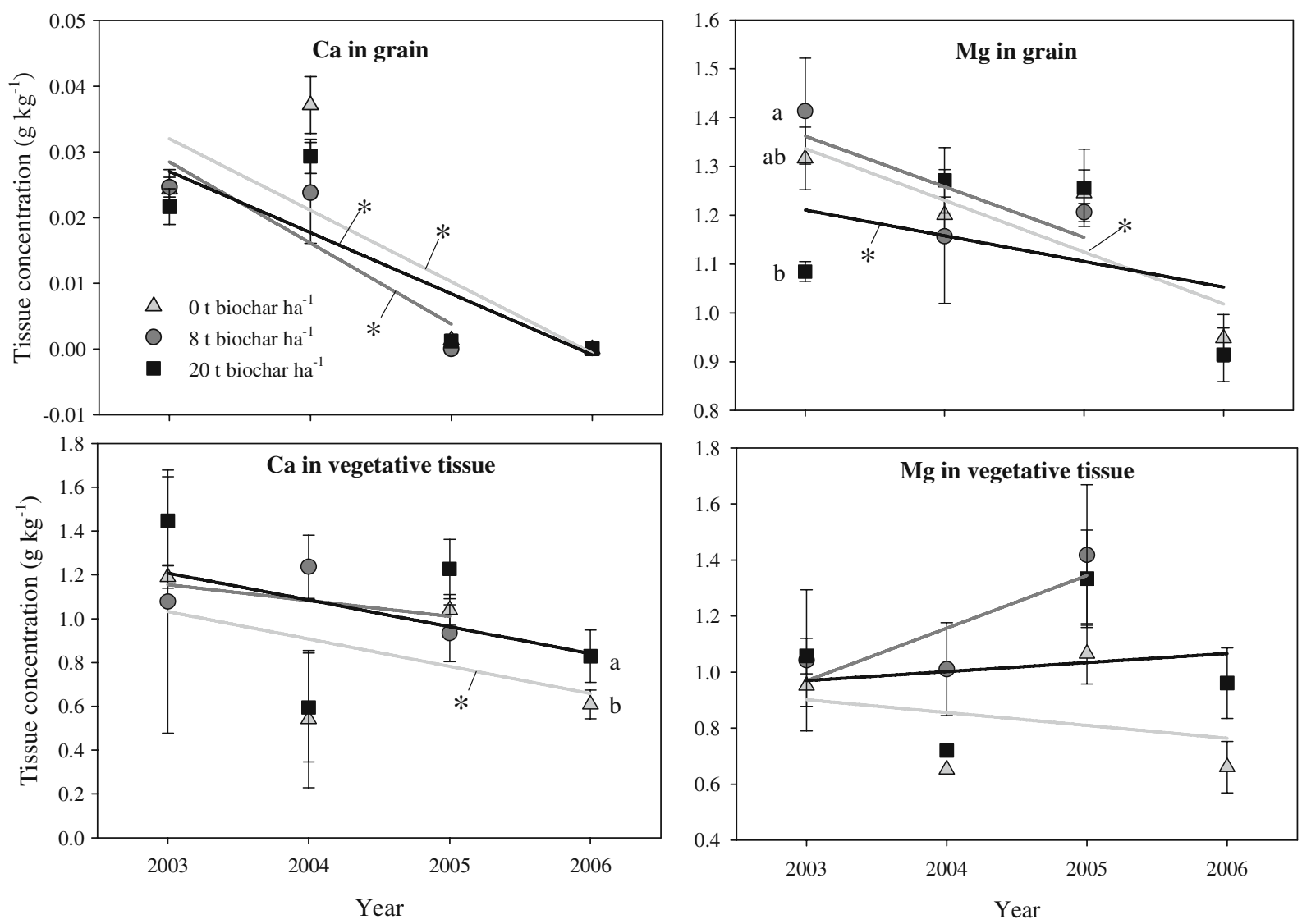

Fig. 4 Maize tissue concentrations of $\mathrm{Ca}$ and $\mathrm{Mg}$ during 4 years after biochar application to a Colombian savanna Oxisol. Different letters indicate significant differences $(p<0.05)$ between treatments in a single year. * indicates a significant $(p<0.05)$ trend over time

(Table 3). The depth at which amounts of available $\mathrm{Ca}$ and $\mathrm{Mg}$ increased with biochar became greater with time, with the increase being most important at the surface in 2003 , at $5-10 \mathrm{~cm}$ in 2004 , and at $10-20 \mathrm{~cm}$ in 2006. For all biochar application rates, the concentrations of $\mathrm{Ca}$ and $\mathrm{Mg}$ to $30 \mathrm{~cm}$ decreased between 2004 and 2006 by $20-30 \%$, although the trend over time was not statistically significant. The effect of biochar addition on $\mathrm{K}$ availability was greatest in 2003, the year after application. Total C and $\mathrm{N}$ contents were not significantly different between treatments except in 2004, where the control plots contained more total $\mathrm{C}$ and $\mathrm{N}$ below the surface.

In 2004 and 2006, soil pH was significantly $(p<0.05)$ higher when biochar had been applied, at the depths where $\mathrm{Ca}$ and $\mathrm{Mg}$ availability was also significantly greater (Table 3 ). No statistically significant differences $(p>0.05)$ were observed for measurements of potential and effective CEC, exchangeable acidity and BS (see online supplementary material). Potential CEC as determined from PZNC equations was $18.8 \mathrm{mmol}_{\mathrm{c}} \mathrm{kg}^{-1}$ for the control and $81.2 \mathrm{mmol}_{\mathrm{c}} \mathrm{kg}^{-1}$ for biochar-amended soil (see online supplementary material).

\section{Discussion}

Yield increases with biochar application have been documented in controlled environments as well as in the field (reviewed by Blackwell et al. 2009; Chan and Xu 2009; Lehmann and Rondon 2006; also Asai et al. 2009). Reported biochar application rates ranged from $<1$ to over $100 \mathrm{t} \mathrm{ha}^{-1}$, and reported percent yield increases over comparable controls ranged from less than $10 \%$ to over $200 \%$. Such high variation likely stems from the large range of biochar application rates, crops and soil types used. However, only a 
Table 3 Properties of a Colombian savanna Oxisol 1, 2 and 4 years after biochar addition in 2002. Different letters indicate significant differences between treatment means within single years and depths $(n=3)$. Letters not shown when differences not significant

\begin{tabular}{|c|c|c|c|c|c|c|c|c|c|c|c|}
\hline \multirow{3}{*}{$\begin{array}{l}\text { Year } \\
\\
2003\end{array}$} & \multirow{3}{*}{$\begin{array}{l}\text { Biochar application rate } \\
\left(\mathrm{t} \mathrm{ha}^{-1}\right) \\
0\end{array}$} & \multirow{3}{*}{$\begin{array}{l}\text { Depth } \\
\frac{(\mathrm{m})}{0-0.05}\end{array}$} & \multirow{3}{*}{$\begin{array}{l}\mathrm{pH} \\
\mathrm{KCl} \\
3.91\end{array}$} & \multicolumn{6}{|c|}{ Available } & \multicolumn{2}{|l|}{ Total } \\
\hline & & & & \multicolumn{6}{|c|}{$\left(\mu \mathrm{g} \mathrm{g} \mathrm{soil}^{-1}\right)$} & \multicolumn{2}{|c|}{ 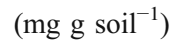 } \\
\hline & & & & $128.6 b$ & $57.1 \mathrm{~b}$ & 29.9 & 12.8 & $0.105 b$ & $1,383.1$ & 21.2 & 1.27 \\
\hline & & $0.05-0.1$ & 3.94 & 143.2 & 54.1 & 2.1 & 0.2 & 0.115 & $1,392.0$ & 20.9 & 1.25 \\
\hline & & $0.1-0.2$ & 3.94 & 44.5 & 21.8 & $<\operatorname{det}$ & $<\operatorname{det}$ & $<$ det & $1,420.7$ & 14.5 & 0.85 \\
\hline & & $0.2-0.3$ & $3.97 \mathrm{a}$ & 11.1 & 7.1 & $<\operatorname{det}$ & $<\operatorname{det}$ & $<$ det & $1,424.7$ & 11.4 & 0.67 \\
\hline & 20 & $0-0.05$ & 4.17 & $288.8 \mathrm{a}$ & $93.7 \mathrm{a}$ & 54.9 & 15.1 & $0.726 a$ & $1,251.3$ & 22.8 & 1.21 \\
\hline & & $0.05-0.1$ & 4.06 & 178.5 & 63.5 & 12.7 & 1.4 & 0.193 & $1,299.1$ & 22.6 & 1.18 \\
\hline & & $0.1-0.2$ & 3.92 & 36.0 & 17.6 & $<$ det & $<\operatorname{det}$ & $<$ det & $1,345.0$ & 12.3 & 0.76 \\
\hline & & $0.2-0.3$ & $3.90 \mathrm{~b}$ & 7.3 & 5.5 & $<\operatorname{det}$ & $<\operatorname{det}$ & $<$ det & $1,390.8$ & 10.9 & 0.65 \\
\hline \multirow[t]{8}{*}{2004} & 0 & $0-0.05$ & 3.80 & $97.6 \mathrm{~b}$ & 56.6 & 49.2 & 7.2 & 0.076 & $1,304.1$ & 22.9 & 1.18 \\
\hline & & $0.05-0.1$ & $3.85 b$ & $113.4 b$ & $45.4 b$ & 15.1 & 0.1 & $0.087 \mathrm{~b}$ & $1,323.8$ & $25.0 \mathrm{a}$ & 1.11 \\
\hline & & $0.1-0.2$ & 3.86 & 99.4 & 36.7 & 2.7 & $<\operatorname{det}$ & 0.033 & $1,300.5$ & $22.1 \mathrm{a}$ & $1.33 \mathrm{a}$ \\
\hline & & $0.2-0.3$ & 3.94 & 37.7 & 20.0 & $<\operatorname{det}$ & $<\operatorname{det}$ & $<$ det & $1,294.7$ & $18.5 \mathrm{a}$ & $0.76 \mathrm{a}$ \\
\hline & 20 & $0-0.05$ & 3.94 & 196.6a & 77.1 & 43.9 & 8.3 & 0.331 & $1,258.4$ & 23.6 & 1.14 \\
\hline & & $0.05-0.1$ & $4.10 \mathrm{a}$ & $265.8 \mathrm{a}$ & $91.8 \mathrm{a}$ & 11.3 & $<\operatorname{det}$ & $0.501 \mathrm{a}$ & $1,183.5$ & $22.1 \mathrm{~b}$ & 0.95 \\
\hline & & $0.1-0.2$ & 4.09 & 161.0 & 65.4 & $<\operatorname{det}$ & $<$ det & 0.138 & $1,228.9$ & $17.7 b$ & $0.80 \mathrm{~b}$ \\
\hline & & $0.2-0.3$ & 3.98 & 68.7 & 32.6 & $<\operatorname{det}$ & $<\operatorname{det}$ & $<$ det & $1,248.4$ & $11.1 \mathrm{~b}$ & $0.49 \mathrm{~b}$ \\
\hline \multirow[t]{18}{*}{2006} & 0 & $0-0.05$ & 3.86 & 116.8 & 54.7 & 53.8 & 48.8 & 0.137 & $1,333.9$ & 19.9 & 1.22 \\
\hline & & $0.05-0.1$ & $3.89 \mathrm{~b}$ & 120.6 & 44.6 & 33.0 & 10.5 & $0.133 b$ & $1,358.0$ & 20.3 & 1.21 \\
\hline & & $0.1-0.2$ & 3.93 & $30.1 \mathrm{c}$ & $14.6 \mathrm{~b}$ & 15.4 & $<\operatorname{det}$ & $<$ det & $1,107.6$ & 15.9 & 0.95 \\
\hline & & $0.2-0.3$ & 3.99 & 12.0 & 8.4 & 2.7 & $<\operatorname{det}$ & $<$ det & $1,317.6$ & 10.9 & 0.64 \\
\hline & & $0.3-0.6$ & 4.13 & 4.9 & 7.9 & 16.2 & $<\operatorname{det}$ & $<$ det & $1,275.3$ & 7.3 & 0.44 \\
\hline & & $0.6-1.2$ & 4.27 & 11.0 & 10.8 & 11.3 & $<\operatorname{det}$ & $<$ det & $1,146.2$ & 4.6 & 0.35 \\
\hline & & $1.2-2.0$ & 4.17 & 8.1 & 10.4 & 8.5 & $<\operatorname{det}$ & $<$ det & $1,134.0$ & 3.1 & 0.31 \\
\hline & 8 & $0-0.05$ & 3.87 & 71.4 & 37.8 & 58.3 & 25.4 & 0.035 & $1,358.1$ & 24.3 & 1.37 \\
\hline & & $0.05-0.1$ & $3.93 \mathrm{ab}$ & 130.4 & 44.6 & 39.0 & 6.5 & $0.179 b$ & $1,334.6$ & 21.7 & 1.24 \\
\hline & & $0.1-0.2$ & 3.99 & $86.4 \mathrm{~b}$ & $32.7 \mathrm{a}$ & 12.7 & $<\operatorname{det}$ & 0.028 & $1,334.2$ & 16.8 & 1.02 \\
\hline & & $0.2-0.3$ & 3.96 & 23.3 & 13.1 & 2.1 & $<\operatorname{det}$ & $<$ det & $1,333.5$ & 12.0 & 0.71 \\
\hline & 20 & $0-0.05$ & 3.84 & 133.1 & 55.3 & 48.2 & 27.4 & 0.223 & $1,293.3$ & 25.3 & 1.24 \\
\hline & & $0.05-0.1$ & $4.03 \mathrm{a}$ & 213.5 & 72.1 & 22.5 & 9.2 & $0.468 \mathrm{a}$ & $1,238.2$ & 20.1 & 1.51 \\
\hline & & $0.1-0.2$ & 4.00 & $126.5 \mathrm{a}$ & $46.3 \mathrm{a}$ & 12.0 & 0.1 & 0.093 & $1,271.6$ & 13.9 & 0.91 \\
\hline & & $0.2-0.3$ & 3.94 & 24.5 & 12.8 & 1.5 & $<\operatorname{det}$ & $<$ det & $1,290.6$ & 10.5 & 0.64 \\
\hline & & $0.3-0.6$ & 4.09 & 12.6 & 10.7 & 19.9 & $<\operatorname{det}$ & $<$ det & $1,292.2$ & 8.2 & 0.49 \\
\hline & & $0.6-1.2$ & 4.19 & 13.4 & 12.4 & 10.2 & $<\operatorname{det}$ & $<$ det & $1,136.6$ & 5.0 & 0.37 \\
\hline & & $1.2-2.0$ & 4.13 & 7.6 & 8.2 & 16.1 & $<\operatorname{det}$ & $<$ det & $1,142.6$ & 4.0 & 0.35 \\
\hline
\end{tabular}

$<$ det below detection limit, $n / a$ data not available

handful of reported field experiments took place over more than 1 year. Steiner et al. (2007) reported cumulative yield increases of rice and sorghum on a Brazilian Amazon Oxisol of approximately $75 \%$ after four growing seasons over 2 years, when $11 \mathrm{t} \mathrm{ha}^{-1}$ biochar was applied at the beginning of the experiment. In a degraded Kenyan Oxisol, Kimetu et al. (2008) found a doubling of cumulative maize yield 
after three repeated biochar applications of $7 \mathrm{tha}^{-1}$ over 2 years. In both of these studies and as shown in the study reported here, inorganic fertilizers were applied equally in both the biochar-amended and the non-amended control. Here, the percent yield increase with biochar application increased gradually over time up to 3 years after application. A large decrease in overall yields was observed in the fourth year, accompanied by an even greater beneficial effect of biochar. A progressive increase in the beneficial effect of biochar over time was also observed by Steiner et al. (2007). This shows that biochar application to soil can provide increasing benefits over time.

Potassium availability was increased the most by biochar application in the year following its application, and this likely results directly from the considerable amounts of $\mathrm{K}$ that were added along with the biochar (Table 1) from which it is readily leached. Similar results for K were obtained by Lehmann et al. (2003) 37 days after wood biochar was added to an Oxisol from the Brazilian Amazon, by Chan et al (2007) 42 days after applying green waste biochar to an Australian Alfisol, and by Rondon et al. (2007) 75 days after wood biochar addition to the same soil as in the present study. However, the greater availability of this nutrient with biochar did not persist beyond the year after application. Steiner et al. (2007) did not observe greater $\mathrm{K}$ availability after one cropping season when wood biochar was added to a Brazilian Amazon Oxisol, but the biochar used contained small amounts of K. Several nutrients may be supplied in considerable amounts with biochar, depending on feedstock (Gaskin et al. 2008). However, the application of these nutrients with biochar is unlikely to provide benefits for crop nutrition on the long term.

Biochar had the most significant effect on the availability of $\mathrm{Ca}$ and $\mathrm{Mg}$, as well as $\mathrm{Sr}$ which was applied with fertilizer. In contrast to $\mathrm{K}$, this increase in availability was not a result of nutrient release, because the amount of available $\mathrm{Ca}, \mathrm{Mg}$ and $\mathrm{Sr}$ applied with biochar (6.6, 1.0 and $0.05 \mathrm{~kg} \mathrm{ha}^{-1}$, respectively) in 2002 is negligible, and mineralization of biochar in this environment is very slow (approx. $2 \%$ over 2 years) (Major et al. 2010). Calcium and Mg were applied as dolomite in 2002, and in small amounts with fertilizer thereafter. These nutrients are prone to extensive leaching in Oxisols (Cahn et al. 1993; Ernani et al. 2006). Although $\mathrm{Ca}$ and $\mathrm{Mg}$ stocks declined after 2004, $\mathrm{Ca}$ and $\mathrm{Mg}$ loss over time was lower with biochar application. Therefore, biochar helped mitigate the loss of applied $\mathrm{Ca}$ and $\mathrm{Mg}$ in the rooting zone, as also shown by the fertilizer-applied $\mathrm{Sr}$.

In 2006, the $\mathrm{Ca}$ and $\mathrm{Mg}$ contents of maize flag leaves at tasseling were significantly greater when biochar was applied. However, all flag leaf $\mathrm{Ca}$ and $\mathrm{Mg}$ contents observed here are still considered marginal for maize (Bergmann 1986). This, combined with the declining stocks of available $\mathrm{Ca}$ and $\mathrm{Mg}$ and the decrease in yield and HI in 2006 indicate that the system was $\mathrm{Ca}$ and $\mathrm{Mg}$ limited, and that the retention of these nutrients by biochar is responsible for the maize yield increases observed. Indeed, in 2006 available $\mathrm{Ca}$ and $\mathrm{Mg}$ amounts in the soil to a depth of $30 \mathrm{~cm}$ were lowest, but the beneficial effects of biochar on $\mathrm{Ca}$ and $\mathrm{Mg}$ nutrition were the greatest relative to the unamended control. The strong overall decline in maize yields in 2006 is attributed to declining $\mathrm{Ca}$ and $\mathrm{Mg}$ soil stocks.

CEC increased only slightly after biochar additions that caused a significant increase, however, in $\mathrm{pH}$. Despite the low increase in $\mathrm{CEC}, \mathrm{Ca}$ and $\mathrm{Mg}$ uptake by crops was greater (Fig. 3) and leaching lower with biochar (Major 2009). If biochar indeed improved crop nutrition by $\mathrm{Ca}$ and $\mathrm{Mg}$ retention, then very low increases in CEC were sufficient.

Apart from direct nutrient additions or nutrient retention with biochar, other authors have attributed increases in crop yields with biochar addition to its effect on soil pH (Rondon et al. 2007; Van Zwieten et al. 2007; Yamato et al. 2006), and to often pH-related increases in nutrient availability and/or reductions in $\mathrm{Al}^{3+}$ availability (Lehmann et al. 2003; Rondon et al. 2007; Yamato et al. 2006). Improvements to soil physical properties, such as reduced soil strength of a hard-setting soil (Chan et al. 2007) have also been offered as explanations for yield increases with biochar. The effects of biochar application in the field on soil biota have been poorly studied. However, improved root colonization by mycorrhizal fungi with biochar has been shown (reviewed by Warnock et al. 2007). Here, yield improvements are attributed mainly to $\mathrm{pH}$ increase and nutrient retention.

\section{Conclusions}

A single biochar application to an infertile, acidic tropical soil improved crop yields up to at least 
4 years after application. This indicates that a single biochar application may provide benefits over several cropping seasons, although longer-term studies are still lacking and needed to determine when a steadystate is reached or if and when a decline starts to occur. Biochar could be a valuable tool for the management of agroecosystems in humid tropical regions of the world, where both industrial and subsistence agriculture are practiced. Although biochar may conceivably enhance crop growth through several mechanisms (microbiologically or through improved soil physical properties, for example), improved $\mathrm{pH}$ and base cation retention in the rooting zone likely caused improved crop nutrition in the studied acid soil under high rainfall conditions.

Acknowledgements We would like to express our appreciation to Pedro Herrera, Gonzalo Rojas and Maria del Pilar Hurtado for their friendship and dedicated help in the field. Support for J. Major was provided by a Canada Graduate Scholarship from the Natural Sciences and Engineering Research Council of Canada, and by the Saltonstall Fellowship from the Department of Crop and Soil Sciences at Cornell University. Field and laboratory work was supported by grants from Cornell's Center for the Environment, the Bradfield award from Cornell's Department of Crop and Soil Sciences, Cornell's National Science Foundation (NSF)Integrative Graduate Education and Research Traineeship (IGERT) program, as well as research travel grants from Cornell's Graduate School. The Centro Internacional de Agricultura Tropical (CIAT) funded the establishment and management of all field operations for this work.

\section{References}

Aberg G (1995) The use of natural strontium isotopes as tracers in environmental-studies. Water Air Soil Pollut 79:309-322

Asai H, Samson BK, Haefele SM, Songyikhangsuthor K, Homma K, Kiyono Y, Inoue Y, Shiraiwa T, Horie T (2009) Biochar amendment techniques for upland rice production in Northern Laos 1. Soil physical properties, leaf SPAD and grain yield. Field Crops Res 111:81-84

Baligar VC, Bennett OL (1986) Outlook on fertilizer use efficiency in the tropics. Fertil Res 10:83-96

Bergmann H (1986) Ernährungsstörungen bei Kulturpflanzen: Visuelle und analytische Diagnose. VEB Gustav Fischer Verlag, Jena

Blackwell P, Riethmuller G, Collins M (2009) Biochar application to soil. In: Lehmann J, Joseph S (eds) Biochar for environmental management: science and technology. Earthscan, London, pp 207-226

Bol R, Amelung W, Friedrich C, Ostle N (2000) Tracing dung-derived carbon in temperate grassland using 13C natural abundance measurements. Soil Biol Biochem 32:1337-1343
Brown R (2009) Biochar production technology. In: Lehmann J, Joseph S (eds) Biochar for environmental management: science and technology. Earthscan, London, pp 127-146

Cahn MD, Bouldin DR, Cravo MS, Bowen WT (1993) Cation and nitrate leaching in an Oxisol of the Brazilian Amazon. Agron J 85:334-340

Chan KY, Xu Z (2009) Biochar: nutrient properties and their enhancement. In: Lehmann J, Joseph S (eds) Biochar for environmental management: science and technology. Earthscan, London, pp 85-106

Chan KY, Van Zwieten L, Meszaros I, Downie A, Joseph S (2007) Agronomic values of greenwaste biochar as a soil amendment. Aust J Soil Res 45:629-634

Cheng CH, Lehmann J, Thies JE, Burton SD, Engelhard MH (2006) Oxidation of black carbon by biotic and abiotic processes. Org Geochem 37:1477-1488

Cheng CH, Lehmann J, Engelhard M (2008) Natural oxidation of black carbon in soils: changes in molecular form and surface charge along a climosequence. Geochim Cosmochim Acta 72:1598-1610

Diels J, Vanlauwe B, van der Meersh MK, Sanginga N, Merck RJ (2004) Long term soil organic carbon dynamics in a subhumid tropical climate: ${ }^{13} \mathrm{C}$ data and modeling with ROTHC. Soil Biol Biochem 36:1739-1750

Ernani PR, Miquelluti DJ, Fontoura SMV, Kaminski J, Almeida JA, Garrity DP (2006) Downward movement of soil cations in highly weathered soils caused by addition of gypsum. Commun Soil Sci Plant Anal 37:571-586

Garrity DP (2004) Agroforestry and the achievement of the millenium development goals. Agroforest Syst 61:5-17

Gaskin JW, Steiner C, Harris K, Das KC, Bibens B (2008) Effect of low-temperature pyrolysis conditions on biochar for agricultural use. T Asabe 51:2061-2069

Glaser B, Lehmann J, Zech W (2002) Ameliorating physical and chemical properties of highly weathered soils in the tropics with charcoal - a review. Biol Fert Soils 35:219-230

Goldberg ED (1985) Black carbon in the environment: properties and distribution. Wiley, New York

Jenkinson DS, Ayanaba A (1977) Decomposition of carbon-14 labeled plant material under tropical conditions. Soil Sci Soc Am J 41:912-915

Kimetu J, Lehmann J, Ngoze SO, Mugendi DN, Kinyangi JM, Riha S, Verchot L, Recha JW, Pell AN (2008) Reversibility of soil productivity decline with organic matter of differing quality along a degradation gradient. Ecosystems 11:726-739

Krull E, Swanston CW, Skjemstad JO, McGowan JA (2006) Importance of charcoal in determining the age and chemistry of organic carbon in surface soils. J Geophys Res Biogeosciences 111:G04001

Lehmann J, Rondon M (2006) Bio-char soil management on highly weathered soils in the humid tropics. In: Uphoff NT et al (eds) Biological approaches to sustainable soil systems. CRC/Taylor \& Francis, Boca Raton, pp 517-530

Lehmann J, Weigl D, Peter I, Droppelmann K, Gebauer G, Goldbach H, Zech W (1999) Nutrient interactions of alley-cropped Sorghum bicolor and Acacia saligna in a runoff irrigation system in Northern Kenya. Plant Soil 210:249-262 
Lehmann J, da Silva JP Jr, Rondon M, Cravo MS, Greenwood J, Nehls T, Steiner C, Glaser B (2002) Slash-and-char-a feasible alternative for soil fertility management in the central Amazon? 17th World Congress of Soil Science, Bangkok, Paper No. 449

Lehmann J, da Silva JJP, Steiner C, Nehls T, Zech W, Glaser B (2003) Nutrient availability and leaching in an archaeological Anthrosol and a Ferralsol of the Central Amazon basin: fertilizer, manure and charcoal amendments. Plant Soil 249:343-357

Liang B, Lehmann J, Solomon D, Kinyangi J, Grossman J, O'Neill B, Skjemstad JO, Thies J, Luizao FJ, Petersen J, Neves EG (2006) Black carbon increases cation exchange capacity in soils. Soil Sci Soc Am J 70:1719-1730

Lobe I, Amelung W, Du Preez CC (2001) Losses of carbon and nitrogen with prolonged arable cropping from sandy soils of the South African Highveld. Eur J Soil Sci 52:93-101

Major J (2009) Biochar application to a Colombian savanna Oxisol: fate and effect on soil fertility, crop production and soil hydrology. PhD Thesis, Cornell University, NY

Major J, Lehmann J, Rondon M, Goodale C (2010) Fate of soil-applied black carbon: downward migration, leaching and soil respiration. Glob Chang Biol 16:1366-1379

Mehlich A (1984) Mehlich-3 soil test extractant - a modification of Mehlich-2 extractant. Commun Soil Sci Plant Anal 15:1409-1416

Naude SM (1927) Information on Nessler's reagent (in German). Z Phys Chem StoÉchiom Verwandtschlehre 125:98-110

Pessenda LCR, Gouveia SEM, Aravena R (2001) Radiocarbon dating of total soil organic matter and humin fraction and its comparison with $14 \mathrm{C}$ ages of fossil charcoal. Radiocarbon 43:595-601

Renck A, Lehmann J (2004) Rapid water flow and transport of inorganic and organic nitrogen in a highly aggregated tropical soil. Soil Sci 169:330-341

Rippstein G, Amezquita E, Escobar G, Grollier C (2001) Condiciones naturales de la sabana. In: Rippstein $\mathrm{G}$ et al (eds) Agroecologia y Biodiversidad de las Sabanas en los Llanos Orientales de Colombia. Centro Internacional de Agricultura Tropical (CIAT), Cali, pp 1-21

Rondon M, Lehmann J, Ramirez J, Hurtado M (2007) Biological nitrogen fixation by common beans (Phaseolus vulgaris L.) increases with bio-char additions. Biol Fert Soils 43:699-708

SAS Institute Inc. (2003) SAS version 9.1. Cary NC
Schmidt MWI, Noack AG (2000) Black carbon in soils and sediments: analysis, distribution, implications, and current challenges. Glob Biogeochem Cycles 14:777-793

Senesi N, Polemio M, Lorusso L (2005) Evaluation of barium, rubidium and strontium contents in commercial fertilizers. Nut Cycl Agroecosys 4:135-144

Skjemstad JO, Clarke P, Taylor JA, Oades JM, McClure SG (1996) The chemistry and nature of protected carbon in soil. Aust J Soil Res 34:251-271

Soil Survey Staff (1994) Key to soil taxonomy. Pocahontas Press, Blacksburg VA USA

Steiner C, Teixeira WG, Lehmann J, Nehls T, de Macedo JLV, Blum WEH, Zech W (2007) Long term effects of manure, charcoal and mineral fertilization on crop production and fertility on a highly weathered Central Amazonian upland soil. Plant Soil 291:275-290

Steiner C, Glaser B, Teixeira WG, Lehmann J, Blum WEH, Zech W (2008) Nitrogen retention and plant uptake on a highly weathered central Amazonian Ferralsol amended with compost and charcoal. J Plant Nutr Soil Sci 171:893-899

Tiessen H, Cuevas E, Chacon P (1994) The role of soil organic matter in sustaining soil fertility. Nature 371:783-785

van Wambeke A (1992) Soils of the Tropics. McGraw-Hill, New York

Van Zwieten L, Kimber S, Downie A, Chan KY, Cowie A, Wainberg R, Morris S (2007) Papermill char: benefits to soil health and plant production. Proceedings of the Conference of the International Agrichar Initiative, 30 April-2 May 2007, Terrigal Australia

Wang JJ, Harrell D, Henderson RE, Bell PF (2004) Comparison of soil-test extractants for phosphorus, potassium, calcium, magnesium, sodium, zinc, copper, manganese, and iron in Louisiana soils. Commun Soil Sci Plant Anal 35:145-160

Warnock DD, Lehmann J, Kuyper TW, Rillig MC (2007) Mycorrhizal responses to biochar in soil-concepts and mechanisms. Plant Soil 300:9-20

Yamato M, Okimori Y, Wibowo IF, Anshori S, Ogawa M (2006) Effects of the application of charred bark of Acacia mangium on the yield of maize, cowpea and peanut, and soil chemical properties in South Sumatra, Indonesia. Soil Sci Plant Nutr 52:489-495

Zingore S, Manyame C, Nyamugafata P, Giller KE (2005) Long-term changes in organic matter of woodland soils cleared for arable cropping in Zimbabwe. Eur J Soil Sci 56:727-736 